\title{
STRATEGIC BEHAVIOURS TO PRESERVE CURRICULUM STUDIES AS A FIELD
}

\author{
COMPORTAMENTOS ESTRATÉGICOS PARA PRESERVAR OS ESTUDOS DE CURRÍCULO \\ COMO UMA ÁREA
}

COMPORTAMIENTOS ESTRATÉGICOS PARA PRESERVAR LOS ESTUDIOS DEL CURRÍCULO COMO UN ÁREA

David Callejo Pérez ${ }^{1}$

Donna Adair Breault ${ }^{2}$

\begin{abstract}
${ }^{1} P h D$ in Education, Educational, Instructional and Curricular Supervision from Florida International University. Associate Provost of Saginaw Valley State University (SVSU), Saginaw, MI. USA.
\end{abstract}

${ }^{2} \mathrm{PhD}$ in Curriculum and Supervision from Georgia State University. Dean of the Dwight Schar College of Education of Ashland University (ASHLAND), Ashland, OH, USA.

\begin{abstract}
I $n$ the last ten years, professors in the field of curriculum studies have seen the impact of their programs decrease. In the midst of these challenges, many of those involved in teaching this subject are seeking to re-align themselves to maintain complicated conversations at the risk of losing programs altogether. This work explores the historical and organizational contexts, in order to offer strategic trajectories for curriculum studies to connect in new ways. Our article is not a treatise on the demise of curriculum studies doctoral programs, but rather, an evaluation of the dramatic shifts taking place in this field. The concerns in our essay are contextualized within the changing nature of education and doctoral programs. We argue that curriculum studies does not fit the new models of graduate work because it is struggling with its identity, and has eschewed most practical applications of theory in order to bridge the divide among the various perspectives in the field, and their role in curriculum work. The curriculum has historically served a critical and unifying role in education to understand the daily lives of educators; support the reflective process in teaching; and enhance the valuation of education as policy. With this in mind, we argue that in order for curriculum studies to survive, we need to find new ways of connecting practice and policy. Keywords: Curriculum Studies; Curriculum History; Doctoral Education; Curriculum Theory.
\end{abstract}

Resumo: Nos últimos dez anos, os professores da área de estudos do currículo assistiram ao encolhimento de seus programas. Em meio a estes desafios, muitos dos envolvidos no ensino do tema estão buscando um realinhamento para manter diálogos complicados, com risco de perderem seus programas. O presente trabalho explora os contextos histórico e organizacional para buscar trajetórias estratégicas para que os estudos do currículo se conectem em novas formas. Nosso artigo não pretende ser um tratado sobre a morte dos programas de doutorado na área de estudos do currículo, mas sim uma avaliação das mudanças drásticas que estão acontecendo na área. As preocupações em nosso trabalho estão contextualizadas na natureza mutante da educação e dos programas de doutorado. Argumentamos que os estudos do currículo não se encaixam nos novos modelos de trabalhos da pósgraduação, pois buscam sua identidade, se afastam das aplicações mais práticas da teoria para tentar reparar a lacuna que divide as várias perspectivas da área e seu papel no trabalho sobre currículo. Historicamente, o currículo tem se prestado a um trabalho crítico e unificador na educação para entender a vida cotidiana dos educadores; dar suporte ao processo de ensino reflexivo; e melhorar a valorização da educação como política. Com isto em mente, consideramos que, para que a área 
de estudos do currículo sobreviva, precisamos encontrar novas formas de conectar prática e política. Palavras chave: Estudos do Currículo; História do Currículo; Educação Doutoral; Teoria do Currículo.

Resumen: En los últimos diez años, los profesores del área de estudios del currículo presenciaron la reducción de sus programas. En medio a estos desafíos, muchos de los involucrados en la enseñanza del tema, están buscando un realineamiento para mantener los diálogos complicados, con riesgo de perder todos sus programas. El presente trabajo explora los contextos históricos y organizacionales para buscar trayectorias estratégicas para que los estudios del currículo se conecten en nuevas formas. Nuestro artículo no pretende ser un tratado sobre la muerte de los programas de doctorado en el área de estudio del currículo, pero si una evaluación de los cambios drásticos que están sucediendo en el área. Las preocupaciones en nuestro trabajo están contextualizadas en la naturaleza cambiante de la educación y de los programas de doctorado. Argumentamos que los estudios del currículo no se encajan en los nuevos modelos de trabajos de posgrado, pues buscan su identidad, se distancian de las aplicaciones más prácticas de la teoría para intentar reparar el vacío que divide las diferentes perspectivas del área y su papel en el trabajo sobre el currículo. Históricamente, el currículo se ha prestado a un trabajo crítico y unificador en la educación para entender la vida cotidiana de los educadores; dar soporte al proceso de enseñanza reflexiva y mejorar el valor de la educación como política. Con esto en mente, consideremos que, para que el área de estudios del currículo sobreviva, necesitamos encontrar nuevas formas de conectar práctica y política. Palabras clave: Estudios del Currículo; Historia del Currículo; Educación Doctoral; Teoría del Currículo.

Curriculum studies in the United States has become an increasingly elusive field, struggling to find its place in colleges of education. In the last ten years, many professors of curriculum studies have seen their programs disappear as departments have been reorganized, with curriculum studies being incorporated into other programs, such as teacher education, educational foundations, or educational leadership. In many colleges of education, the curriculum programs that remain are far more vocational in nature, focusing on the skills needed by discipline-specific methodologists or general teacher educators. As a result of these changes, many doctoral students in the USA have limited exposure to curriculum theory, and scholars of curriculum studies may carry very different titles within their institutions. The graduates of curriculum programs who are able to obtain positions often find that, at best, they obtain work teaching curriculum courses sporadically-and curriculum theory courses even less.

This challenge is particularly daunting in view of the role ambiguity that is now characteristic of this field (Lawn \& Barton 2012). This role ambiguity takes its toll on new assistant professors, who find positions that are, at best, only indirectly related to what they studied in their doctoral programs. In order to pursue teaching and publishing in the field of curriculum studies, they must first fulfil their other duties expected of them. Moreover, newly qualified professors wishing to produce conference papers and publications in curriculum studies do so at their own professional risk, given that tenure and promotion are awarded by the university judging committees strictly on the basis of the academic appointment for which the professor was hired. And those who do manage to work in the field, and write about curriculum studies, are often obliged to justify their work to their colleagues, who not always recognize curriculum studies as a distinct field. Many departmental administrators take the view that anyone can teach the curriculum courses, because 'We're all curriculum professors, after all'. 
Amidst these challenges, many of those involved in curriculum studies are seeking to align themselves with foundation, interdisciplinary, or alternative education programs in order to maintain the complicated conversations of the field. While these strategic moves provide space among like-minded colleagues, it also puts the field itself at greater risk of extinction. Particularly in periods of recession, prestige-seeking universities are looking at which programs can be cut, as they shift support to areas that are more likely to influence the institutional rankings. As a result, some programs are reduced, absorbed into the remaining programs, or eliminated altogether (Adair Breault and Callejo Perez 2012). With these challenges in mind, we explore the historical and organizational context of the field of curriculum studies, and offer strategic trajectories for curriculum studies to connect within universities in new ways, to sustain the field.

While this phenomenon is particularly prominent in U.S. institutions, we believe it speaks to a critical international conversation about our future. As Carson (2009) states, how do we respond to the "hermeneutic challenge" of reinventing ourselves as professors of curriculum and how do we imagine new possibilities for the field of curriculum studies? In other words, how can the historical patterns of association within a largely U.S. based curriculum studies group, coupled with patterns of organization within U.S. universities, impact on the future of the field nationally, and how can the challenges we face within the United States impact on our capacity to influence policy and internationalize curriculum work? As GaztambideFernandez and Theissen (2012) lament, in spite of numerous calls to internationalize the field, most of the work in curriculum studies emerges from scholars in the United States, Canada, Britain, and Australia. Furthermore, much of the work published by international authors draws its ideological foci from English-speaking philosophers and theorists. Thus, while we do not wish undermine the current efforts to globalize the curriculum conversation, we believe that it is important to examine the history of associations within the field, and to explore how those shifts in association have made curriculum professors in the U.S. vulnerable to recent organizational shifts in U.S. universities.

\section{FROM IMAGINED COMMUNITIES TO IDENTITY FORMATION}

For the past four decades, curriculum scholars have focused on individualized identities at the expense of a common culture. At best, scholars in the field have coalesced into an imagined community (Anderson 1991); imagined because although the members might not know each other, "in the minds of each lives the image of their communion' (6) and community because, 'regardless of the actual inequality and exploitation that may prevail in each, the nation is always conceived as a "deep, horizontal comradeship" (7). While understanding that curriculum discourse and roles stem from these imagined communities, it is nonetheless important to move toward a more authentic community that allows us to enter into a common conversation and, more importantly, common work. Schubert (2010: 77) agrees: 
Curriculum inquiry must be community in the making, wherein curriculum theorists, policy makers, and practitioners listen carefully to one another, share diverse perspectives, experience free, imaginative, and thoughtful inquiry into curriculum matters that matter most so we can take to heart the concerns of disenfranchised individuals and groups, and work into the contradictions, complexities, and diversities of everyday life in curricula of schools and societies.

Thus, it is important to see the role of curriculum studies in the wider context of education as parallel to notions of nation formation. As Schubert (2010: 77) writes "Curriculum scholars need to work with all members of society (including one another)."

Thus, given the threat of imagined communities, how can professors of curriculum studies achieve authentic sovereignty? Greenfeld (1995) emphasizes that the sovereignty of a particular group is based on an individual's identification within a people group to which he or she is loyal. The author goes on to state that nationalism is a social construct that emerges out of a group's contact and interaction with other groups. Proximity favours more interactions among a particular set of individuals who develop a similar mentality and perception of reality. Changes brought about by development and overall structural context accentuate some groups' expectations as opposed to others. An elite shapes these expectations and reinterprets sovereignty, based on the uniqueness of that particular group, which assumes the character of a collective individual possessed by a single will. Some individuals emerge from the collectivity as interpreters of the single will. The reinterpretation of the idea of sovereignty leads a group that is transformed into a nationality to try to transform the social and political structure.

A number of critics have pointed to Western curriculum scholars as the ones who have shaped much of the work in curriculum studies, and have challenged the domination of Western ideology (Carson 2009, Gaztambide-Fernandez and Theissen 2012, Gough 2004, Pinar, 2006). We agree with them. However, we wish to extend the challenge further. Internationalization will not help the field of curriculum studies to achieve authentic sovereignty unless it also includes teachers, administrators, and policy makers. This engagement requires three critical elements: (1) for theorists to have a better understanding the daily lives of educators - this is the human side of policy; (2) for practitioners to see the value of curriculum studies to support the reflective process of teaching; and (3) for scholars and practitioners to recognize that curriculum studies has the potential to connect political, social, and economic issues to educational policy (Reid 2004). By isolating ourselves from the daily lives of practitioners, whether by choice or by policy, theorists have encouraged a 'flight from the field' (Schwab 1969) and have retreated to the periphery, allowing 'a translocation of [the field's] problems and the solving of them from the nominal practitioners of the field to...other[s]' (3). This intentional separation from the field represents a repositioning of the curriculum theorist from the broader curriculum community driving policy into an undesirable remoteness. While this retreat from practice and policy is intellectually appealing, it denies Dewey's (1916) notion that experience - in our case curriculum policy - 'is not a combination of mind and world, subject and object, method and subject, but is a single continuous interaction of a great diversity of energies' (167). 
Professional associations across disciplines offer multiple histories. No one history is not inherently superior to another. It is important, however, to consider any such history as a glimpse into the nature of the field itself. To that end, we believe our organizing, and our professional identities that were forged by virtue of our organizing, represent cultures of practice (Novick 1988) and as such, form "a sprawling collection of assumptions, attitudes, aspirations, and antipathies" resting upon "a commitment to the reality of the past, and to truth as correspondence to that reality" (1). By focusing on one image of the history of our associations, we explore the role that cultures of practice have played among a group of influential scholars over an important period of transition in the field.

Obviously the context of curriculum work is much broader than the specific period and group we have selected here for our focus. However, we believe that the activity represented within this small group over the past six decades reviewed here represent significant shifts in the field, particularly in terms of professional identity, professional association, and the nature of curriculum conversations. Precisely because of the diversity of curriculum studies, we hold that a standardized history is not an appropriate response. We therefore choose to consider modern conceptions of the field in relation to the shifting associations of curriculum professors, as chronicled through a small but influential group of curriculum professors.

Our analysis begins in 1950, the year the Professors of Curriculum was formed. Again, we recognize that this group does not represent the sum total of all work in the field, but we believe that the group's history reflects the organizational history of curriculum, and it is this organizational history that we want to focus on in this article. We are not focusing our efforts on shifts in ideology in curriculum studies - the changing nature of curriculum theorizing - but rather, on the professionalization of the field (Larson 1977). How we define ourselves within our field significantly impacts the direction of our field, and our associations with one another (or, more importantly, our disassociation with one another) impacts the degree to which our professional lives matter to others. In other words, while it is important to consider who we are as individuals and as groups within the field of curriculum studies, it is even more important to consider who we are in relation to academia, policy makers, and the public.

The Professors of Curriculum is an invitation-only group of prominent scholars in the field of curriculum studies. As stated above, the group was formed in 1950, and many of its members have served in a range of leadership positions in other professional organizations, including the Association of Supervision and Curriculum Development (ASCD) and the American Educational Research Association (AERA). In addition, many of its members have served as editors of prominent journals in the field (Adair Breault (Mathis) 1996, Davis, Jr. 1986).

Throughout the early days of the organization, the group was relatively harmonious. Most of the early members were involved in the work of curriculum design and development, consistent with the work of Ralph Tyler. Many had backgrounds in school administration and thus had a close affiliation with the ASCD. In the late 1960s and the early 1970s, this overall 
composition began to change as new scholars entered the field. Due to an increase in federal funding for curriculum development in the 1960s, schools experienced a sudden expansion of services that called for curriculum specialists. This increased need for curriculum specialists resulted in more university programs focusing on curriculum. Also, the role of curriculum professors changed from practitioner to researcher and theorist (Adair Breault (Mathis) 1996, Davis, Jr. 1986, Van Til 1986). With the increasing number of curriculum positions in universities, the new curriculum professors were increasingly younger, and had never served as school administrators. These new scholars, some of whom had entered graduate programs to avoid being drafted into the military, had different foci for their work. Instead of focusing on curriculum development, they were more interested in philosophy and social issues. Marxism, existentialism, humanistic psychology, and/or phenomenology influenced these new scholars. Some, like James MacDonald and Dwayne Huebner, focused their work on aesthetics and spirituality while others, like Michael Apple and Henry Giroux, focused on issues of power and social justice (Adair Breault (Mathis) 1996, Pinar et al. 1995).

As more and more of these new scholars entered the field, they began to prepare more and more new scholars. As a result, the overall ideological composition of the Professors of Curriculum began to change. By the late seventies, papers presented within the group began to reflect on the field and make predictions about its future. In the early eighties, presentations at the Professors of Curriculum meetings focused more on curriculum theorizing and criticism, and generally eschewed practice. These presentations addressed the social implications of schooling and began to question whether problems in schools could be solved. By 1984, in response to the national reports on education, members began to question the role curriculum should play in school improvement. It was also in 1984 that the members first questioned the original purpose of their group and whether it was still appropriate. Throughout the nineteen eighties, the group addressed fewer traditional curriculum issues and focused more on 'reconceptualist' concerns. Topics of the meetings included social activism, women's issues, teacher empowerment, multiculturalism, and democratic schooling (Professors of Curriculum Archives).

The ideological shifts within the group led to organizational shifts. Since the first meeting in 1950, the Professors of Curriculum had met alongside the annual meetings of the ASCD. In the 1980s, however, they added a second meeting at the AERA to accommodate those newer scholars who did not want to attend the ASCD. The exodus of the newer scholars from the ASCD-affiliated meeting was, largely, a response to their focus on research and theory, as well as to the shifting nature of the two organizations. Throughout the nineteen eighties and beyond, the ASCD shifted further away from its progressive roots, and focused increasingly on becoming the largest professional organization in education. While ASCD was expanding and focusing more and more on marketing products, the AERA began shifting its emphasis from largely quantifiable empirical work to qualitative and theoretical work. This was particularly notable in 1992 when Elliot Eisner was president of the organization. Furthermore, the conference fees of the ASCD were increasing substantially, placing a greater financial burden on students who would otherwise would have attended ASCD. At the same time, the AERA's conference registration was, surprisingly, more reasonable, and many of the new scholars 
where required to attend the AERA conference as they worked toward tenure and promotion. Because members of Professors of Curriculum had to attend at least one meeting every three years in order to maintain membership, these shifts in fees were a significant source of stress for those who felt they were being forced to participate in the ASCD in order to retain their membership as Professors.

During the nineteen eighties and early nineties, the Professors of Curriculum continued to meet together at both meetings, but many of the professors grew more and more frustrated by the ASCD's changes, and by the fact that the organization was minimizing the degree to which it acknowledged the group as an affiliate of the larger organization. The group conducted a survey in 1985, to discern whether it should continue to meet at both annual meetings. In response, Esther Zaret warned that attending both meetings would fragment the group. O.L. Davis, Jr. suggested that if a group of scholars wanted to attend the AERA, then they should form a different organization. He noted:

I believe that this small group never intended to be large and always related to ASCD. It would change profoundly if it were to meet at other places without the conversational nature it has fostered. I am not against a different group, but I am for this group, as it is... My purpose in saying this is to affirm my interest in fostering dialogue, friendship, and collegial relationships in as many forms as people find useful. I don't have to/need to be a member of each one ... and am not (Professor of Curriculum Archives: Box 2, File 18).

In 1992, the group invited a representative from the ASCD to respond to its concerns, and her reply at that meeting produced very strong emotions among the members. She dismissed the group's concerns about the changes in the ASCD, and attempted to appease the group by offering the Professors of Curriculum more sessions during the annual meetings. In response, the group charged the two acting factotums, Gerald Firth and George Stansbury, along with the incoming factotum, Dan Marshall, to draft a letter to the ASCD. The letter chastised the organization and indicated that their misunderstanding of the concerns in the meeting was a clear indicator of the changes in the ASCD - a movement away from its progressive heritage into a corporate model. The factotums added that the group would seriously question its future association with the ASCD.

The Professors of Curriculum continued to meet at both the ASCD and the AERA throughout the nineteen nineties and the early 2000s, but the numbers of the ASCD continued to dwindle. By this time, the group had added a third meeting at the American Association of Teaching and Curriculum (AATC), for members who were not attending either the ASCD or the AERA. In view of the costs of meeting rooms and catering at the ASCD, the issue was again raised at the 2007 meeting. The factotum, Louise Allen, stated that less than a dozen professors had met that year at the ASCD, and that the costs of the meeting were substantial. Stephen Fain then made the motion to the group that the Professors should meet only at the AERA, and the motion passed, albeit with several objections, mainly from those members who were attending AATC not the ASCD. 
These shifts in the Professors of Curriculum represent a shift in the association among members of the field. The ideological divisions that began in the late 1960s and early 1970s resulted in organizational divisions that had significant implications on the future of the field, by influencing the way in which future scholars were trained. The traditions in which scholars are trained shape how they conceive the field, and how they will train others. When scholars move toward narrower associations based on a common ideology, their students are exposed to more limited frames of reference from which to engage in research and scholarship. Thus, it is important to consider the shifting cultures of practice that are evident in the way members of our field have shifted their associations with one another in recent years. The Bergamo Conference began in 1978, the American Association of Teaching and Curriculum (AATC) began meeting in 1993, the Curriculum and Pedagogy Group (C and P) began meeting in 2000, and the American Association for the Advancement of Curriculum Studies (AAACS) began in 2001 (and its international group, the IAAACS, began meeting the following year). Three of the four groups are rooted in a reconceptualist ideology, and focus more on social foundations than 'practical' matters of schooling. While some scholars and graduate students have attended multiple conferences, fewer of them are able to do so, as institutions continue to reduce travel funds. As a result, the conversations within curriculum have become 'less complicated', because those that engage with each other tend to share the same ideological assumptions.

Moreover, because curriculum scholars are increasingly focusing on foundational issues, there is a clear organizational void in terms of conversations about practice, which results in limited opportunities for students to enter research-based curriculum programs that are focused on more traditional notions of curriculum. In other words, as demonstrated by the 2008 survey conducted by the Commission on the Status of Curriculum Studies of the American Association for the Advancement of Curriculum Studies (AAACS), through an analysis of both degrees by faculty and readings, many of our curriculum studies programs are preparing students with an increased focus - some might even say exclusivity - on the social foundations (Grumet 2008). While social foundations are very important for understanding curriculum, this preparation puts new scholars at an extreme disadvantage, due to the limited opportunities they will find to teach social foundations. As a result, we have a new generation of graduates from curriculum studies doctoral programs whose training has been almost exclusively based on social foundations. Not only are these students not trained in practical matters, but many are also often 'taught' that addressing practical matters undermines the complex nature of curriculum. Yet, they are graduating with 'curriculum' degrees and applying to colleges of education where notions of curriculum are quite ambiguous. It is likely that these students will not find curriculum studies positions that will allow them to teach social foundations. Instead, they must market themselves for the kinds of positions available. These entry-level positions are often discipline-based or age-specific (e.g. elementary education, maths methods, etc.), and the institutions hiring them will expect them to teach their students practical strategies 
and methods to use in the classroom.

In the past, many graduates with the right academic pedigrees and with some publications were able to overcome the ambiguity of their degrees and secure tenure-line positions. Granted, many had to accept positions that were not actually curriculum studies positions, but because they were tenure-line, they had some discretionary space regarding their research and scholarship. However, the market for tenure-line positions has become more and more competitive. As curriculum studies programs decline along with tenure-line positions, these graduates are competing with other graduates whose degrees are more explicitly aligned with the positions advertised. Often, these graduates, regardless of where they obtained their degrees, are unable to compete. We predict that the situation will only become worse as the professoriate becomes older, and tenure-line positions continue to decline.

\section{THE GRAY AREAS OF THE DISCIPLINE AND THE GRAYING OF THE PROFESSORIATE: THE PROFESSIONAL CONTEXT OF CURRICULUM STUDIES}

A recent headline article in the Chronicle of Higher Education focused on the aging professoriate. According to Williams, (June 2012), data from the US Bureau of Labour Statistics shows that the number of professors aged 65 years or older has more than doubled between 2000 and 2011. At some institutions, one out of every three professors is 60 years or older. Many attribute this phenomenon to the plunging IRAs coming out of the recession. Others note that universities have lost many of their retirement incentives due to budget cuts (Lalwani and Seager 2010), while still others note that the life of a full professor is difficult to give up, as it involves autonomy, power, influence, and flexibility. Since mandatory retirement was repealed in 1994, tenured professors have been able to stay on as long as they want, and many do stay, for as long as they are physically able - some staying well into their 80s (Clark and Hammond 2000, Fogg 2005). When they do retire, many institutions are closing their lines of research or shifting the positions they held from tenure-line to clinical or adjunct positions. After all, if the professors secured comfortable positions for themselves that involved limited teaching and service, then it is difficult to justify a full line to replace them. Moreover, universities are trying to compete with a number of entrepreneurial programs, particularly those from profit-making institutions, and for this, they have to reduce costs and increase organizational flexibility; but tenure-line positions limit their ability to shift their academic programs in order to remain competitive (Adair Breault and Callejo Perez 2012).

The statistics paint a bleak picture for graduates of curriculum programs. In the past ten years, tenure-line positions have declined from one-half to one-third (Greenberg 2012), and this trend is likely to continue. Sixty-nine percent of the university presidents surveyed by the Pew Research Centre indicated that they preferred to have more faculty under long-term or annual contracts (Stripling 2011). Thus, while the curriculum professors of the 1970s entered the field when there were many tenure-line positions to choose from, current graduates are finding, at 
best, two or three actual tenure-line 'curriculum studies' positions posted annually. The drastic increase in clinical and adjunct positions coupled with the increasing rate at which aging faculty are staying in the limited tenure-track positions, means that there will be fewer opportunities for recent graduates to establish professional careers within curriculum studies.

\section{Capturing the market share: The changing nature of EDUCATION DOCTORATES}

As curriculum studies programs continue to focus on foundational issues, and continue to prepare their students for an academic environment that no longer exists, many universities are changing or adding doctoral programs designed for the geographically limited practitioner. Universities such as Penn State and Vanderbilt have developed on-line and/or executive format programs that can typically be completed in three years. Furthermore, regional universities have developed practitioner-based programs that provide a convenient service to placebound practitioners. These programs are rethinking dissertations as the capstone experience, and turning instead to shared projects or other 'applied' and performance-based outcomes. To some degree, these changes have emerged in response to criticisms from Labaree (2004/2006) and Levine (2005). For the most part, however, these changes have been in response to the competition found among other on-line and profit-making institutions.

Most university doctoral programs cannot survive financially on their full-time doctoral students. They also need their part-time students, who may or may not pursue academic positions after they graduate. Many on-line and profit-making institutions have lured these part-time students away from traditional programs with promises of convenience and efficiency. University administrators have responded by calling for new practitioner-focused programs. They are often able to provide these programs using clinical or adjunct faculty, and are often able to charge higher tuition rates because their programs operate out of university extension offices. Reducing delivery costs while increasing revenues reinforces these organizational changes, and since universities are largely mimetic organizations, many are developing programs that 'look like' programs they see in their peer institutions. Programs in educational leadership have adapted to this new market-mind-set more than most programs. Their customer base is often geographically bound and has much to gain through advanced degrees. Other practitioner-based programs, such as graduate programs in technology, have also followed suit.

Graduate programs in curriculum, however, have not. Because curriculum studies struggles with its identity and, more importantly, because it has eschewed most practical applications of theory, it is not a likely candidate for these new and more marketable program designs. While this may seem like good news for curriculum scholars, it should be seen as a warning of potential doom. If increasing numbers of universities continue to reduce the number of traditional doctoral programs, keeping only those with the greatest potential to increase the research profile of their colleges, and if they continue to shift other programs to more entrepreneurial designs, then where does that leave programs that are neither entrepreneurial nor prestigious? Some programs, such as educational research and educational foundations, 
can still survive in many cases, because they are service courses for other programs, but fewer and fewer curriculum courses are seen as necessary in these new programs.

\section{WHAT IF THE SKY IS REALLY FALLING?}

The shifting cultures of practice within curriculum studies and the simultaneous organizational shifts within academia have created the perfect storm for recent graduates in curriculum studies. Because we have eschewed the practical and largely ignored policy, we have created a void - one largely filled by corporate leaders and politically conservative forces. For a time, this void did not affect curriculum scholars much. We could continue in our academic careers without concern for what was going on around us. However, this neglect is beginning to impact the nature of our programs, as well as the future for our graduates.

What once separated doctoral programs in education from most others was a sense of doctoral core that usually
involved curriculum theory, foundations, curriculum history, educational psychology, or instructional leadership.
Whether all these courses, or a combination of them, were part of a program, they provided a common ground,
which was unique to education. However, following the criticisms of Labaree $(2003,2004 / 2006)$ and others,
educational doctoral programs have increased the number of research courses and specializations that resemble
more Arts and Sciences than Education. In spite of these recent shifts, we believe that teaching curriculum
theory, and support programs that help develop curriculum generalists, are central to doctoral education.

William Schubert (1994) writes, 'what is fundamentally curricular and what is fundamentally human are of the same fabric' (26). We believe curriculum theory and development are central to doctoral education. Curriculum studies offer robust images of what is possible in education. It engages us to explore the complexity between science and art (Dewey 1934); practice and theory (Pinar et al. 1995); justice and oppression (Freire 1970); and democracy and totalitarianism (Apple 1988). We further see curriculum theory in the legacy of many scholars: John Franklin Bobbitt, Ralph Tyler, Joseph Schwab, John Dewey, Paulo Freire, Michael Apple, Frantz Fanon, Maxine Greene, Eliot Eisner, William Pinar or Pierre Bourdieu. The questions driving their philosophy of what and how we teach and learn in schools were always centred on the deeper idea that there needed to be an ethical and philosophical force driving the curriculum. Curriculum is at the centre of the most enduring and ephemeral issues in education - controversial as they may seem - and the answer(s) may only be found if we recognize that curriculum provides a liberating (and useful) path toward better understanding educational practices and policy. While some may wish to distance themselves from it, curriculum has historically served a critical and unifying role in education (Schubert 2010). While our current associations in curriculum studies may largely ignore the work of curriculum development and evaluation, the ideas of curriculum professors of the 50s, 60 s and 70 s continue to be cited in footnotes and quoted in chapters and articles. Acknowledging the role of curriculum work does not erase the role and function of theory that has emerged in recent decades. In fact, it has the potential to breathe new life into this vital work.

\section{NEW DIRECTIONS FOR CURRICULUM STUDIES}


Curriculum Studies, as seen in the work of scholars prior to the nineteen-seventies, dealt with policy and practice, but as higher education changed, so too did the role of curriculum scholars and their place within the colleges/schools of education. This fact is lost on most curriculum scholars unless they have experienced it through a loss of appointment or program. Many curriculum scholars have not dealt with the changing nature of curriculum studies like those practitioners who have been involved in educational policy. Thus, critics of curriculum studies have a point. The field of curriculum studies, and by extension, those who define themselves by the field, has not changed alongside the changes in higher education. The construction of individual identity/separation as the driving force of curriculum studies is now simply based on separation or uniqueness.

As Schwab (1969) suggested 40 years ago, language is a unifier. This does not suggest that language emerging from individual and associated curriculum scholars regarding identity and power is not valued and even necessary. It is just not enough. We, like Schwab (1969), suggest that a common language is necessary to re-join the curriculum theorists, practitioners, and policy makers into a comprehensive and ecumenical community that works in synchronization toward a collective purpose. Schwab (1969) clearly states that the field "has reached this unhappy state by inveterate and unexamined reliance on theory in an area where theory is partly inappropriate"(1). This retreat from practice and policy ultimately threatens the work of theorists and results in the disruption of their relationship to the ways that lived experiences connect practices that should be at the heart of the curriculum field.

Without this unifying language and wider social aims, we will become objects shaped by others. Either we will become pawns used to capture a larger market share in more entrepreneurial graduate programs, or we will be inconsequential spokes in the great accreditation machine that has taken over much of teacher education (Bullough, Clark and Patterson 2010, Gilroy 1992, Murray 2000). As universities face radical changes in the design and delivery of their programs, curriculum professors need to look at their associations as a means through which they can respond. Our associations are important because they help shape us as a profession and, as such, they help shape the future of the profession through the graduates of our programs. Our associations cannot combat the dehumanizing effects of the accountability movement or the entrepreneurial initiatives of academia, but they can help us define ourselves in relation to one another. To this end, imagined communities cannot sustain us. A sovereignty formed by intellectual elite - even if that elite is cosmopolitan in nature - cannot sustain us. Transformative change has to reflect on the basic assumption that improving curriculum studies is a complex matter, requiring multiple voices and approaches to curriculum studies, and that it is impossible to ignore the context of the field within the university and, in particular, the varied dimensions of Colleges of Education. The definition of the field ought to emerge from conversations and actions fostered by our associations; which should be rooted in a strong commitment to contribute positively to the challenges facing the field and foster close links among professors.

The cultures of practice found within our associations must address policy and practice related to K-12 and post-secondary education. We need to imagine new roles for curriculum workers, and that includes reclaiming much of the curriculum work that was the focus of the Professors of 
Curriculum five decades ago. In addition, we need to imagine a world to come, and help to prepare future curriculum scholars for that work. Engaging in this work does not relegate us to the inadequate modernist attempts to curriculum reform lamented by Macdonald (2003), Miller (2000) and Doll (1989). By using our associations as a springboard which we work and prepare others for the future of work curriculum, we can engage in the kind of post-modern curriculum work needed today.

REFERENCES

ADAIR BREAULT, M. Professors of curriculum: Reflections of the field. Paper presented at the Annual Meeting of the American Educational Association. 1996. New York, NY.

ADAIR BREAULT, D.; CALLEJO PÉREZ, D. The red light in the ivory tower: Contexts and implications of entrepreneurial education. 2012. New York: Peter Lang.

ANDERSON, B. Imagined communities. 1991. New York: Verso.

APPLE, M. Teachers and texts: A political economy of class and gender relations in education. 1988. New York: Routledge.

BENHAM, B. J. Curriculum theory in the 1970's: The reconceptualist movement. Journal of Curriculum Theorizing, 3(1), Winter, 1981, 162-170.

BULLOUGH, R. V. JR.; CLARK, D. C.; PATTERSON, R. S. Getting in step: Accountability, accreditation and the standardization of teacher education $n$ the United States, Journal of Education for Teaching: International Research and Pedagogy, 29(1), 2010, 35-51.

CALDWELL, L. Scholar activism and the university. Keynote address at the Equity in in the classroom: Partnerships and collaborations conference. Saginaw Valley State University. March 20th 2012.

CALLEJO PÉREZ, D. Curriculum, educational foundations, research and mis-interpretation in the doctoral work of teacher education. Special Section on Future of Teacher Education Curriculum. American Education History Journal, 35(1), Fall 2008, 18-39.

CARSON, T. R. Internationalizing curriculum: Globalization and the worldliness of curriculum studies. Curriculum Inquiry. 39(1), 2009, 145-158.

CLARK, R. L.; HAMMOND, P. B. As professors age, retirement policies need rejuvenating. The Chronicle of Higher Education. June, 2, 2000. (http://chronicle.com/article/As-Professors-AgeRetirement/17680/).

DAVIS, O. L. JR. ASCD and curriculum development: The later years. In W. Van Til (Ed.). ASCD in retrospect: Contributions to the history of the Association for Supervision and Curriculum Development. 1986. Washington D.C.: ASCD.

DAHL, R. After the revolution? 1970/1990. New Haven: Yale University Press).

DEWEY, J. Democracy and education. 1916. New York: Macmillan.

DEWEY, J. Art as experience. 1934. New York: Perigee. 
DOLL, JR, W. E. Foundations for a post-modern curriculum. Journal of Curriculum Studies, 21(3), 1989, 243-253.

DOLL, JR. W. E. A post-modern perspective on curriculum. 1993. New York: Teachers College Press.

EISNER, E. The educational imagination. 1979. New York: Macmillan.

FOGG, P. Advancing in age. The Chronicle of Higher Education, June 3, 2005. (http://chronicle.com/ article/Advancing-in-Age/31009/).

FREIRE, P. Pedagogy of the oppressed. 1970. New York: Continuum.

GAZTAMBIDE-FERNANDEZ, R.; THEISSEN, D. Fomenting flows and internationalizing curriculum studies. Curriculum Inquiry, 42(1), 2012, 1-11.

GILROY, D. P. The political rape of initial teacher education in England and Wales: A JET rebuttal. Journal of Education for Teaching, 18(1), 1992, 5-22.

GOUGH, N. Editorial: A vision for transnational curriculum inquiry. Transnational Curriculum Inquiry, 1(1), 2004, 1-11.

GREENBERG, M. Tenures dirty little secret. The Chronicle of higher education, January 1, 2012. http://chronicle.com/article/Tenure-Dirty-Little-Secret/130185.

GREENFIELD, L. Nationalism: Five roads to modernity. 1995. Cambridge, MA: Harvard University Press.

GRUBB, W. N.; LAZERSON, M. Vocationalism in higher education: The triumph of the education gospel. The Journal of Higher Education. 76(1), 2005, p. 1.

GRUMET, M. Commission on the Status of Curriculum Studies of the American Association for the Advancement of Curriculum Studies (AACS). 2008. Survey of Curriculum Studies.

HABERMAS, J. Postmetaphysical thinking: Philosophical essays. Trans. By W. Hohengarten. 1991. Cambridge, MA: The MIT Press.

HOBSBAWN, E. Interesting times. 2002, London: Allen Lane.

KLIEBARD, H. Forging the American curriculum: Essays in curriculum theory and history. 1992. London: Routledge.

KREYLING, M. Inventing Southern literature. 2001. Jackson, MS: University of Mississippi Press.

LABAREE, D. F. The peculiar problems of preparing educational researchers. Educational Researcher, 32(4), 2003, 13-22.

LABAREE, D. F. The trouble with ed schools. 2004/2006. New Haven, CT: Yale University Press.

LALWANI, N.; SEAGER, I. Some professors defer retirement. Yale Daily News, September 14, 2010. (www.yaledailynews.com/news/2010/sep/14/some-professors-deferring-retirement/).

LARSON, M.S. The rise of professionalism: A sociological analysis. 1977. Berkeley: University of California Press.

LAWN, M.; BARTON, L. Rethinking curriculum studies: A radical approach. 2012. New York: Routledge.

LEVINE, A. Educating school leaders. 2005. Washington, D.C.: The Education Schools Project.

LOONEY, A. Curriculum as policy: Some implications of contemporary policy studies for the analysis 
of curriculum policy, with particular reference to post-primary curriculum policy in the Republic of Ireland. Curriculum Journal, 12(2), 2001, pp. 149-162.

MACDONALD, D. Curriculum change and the post-modern world: Is the school curriculum-reform movement an anachronism? Journal of Curriculum Studies, 35(2), 2003, 139-149.

MILLER, J. L. What's left in the field. . . A curriculum memoir. Journal of Curriculum Studies, 32(2), 2000, 253-266.

MURRAY, F. B. The role of accreditation reform in teacher education. Educational Policy, 14(1), 2000, 40-59.

NOVICK, P. That noble dream: The "objectivity question" and the American historical profession. 1988. Cambridge: Cambridge University Press.

NULL, W. Curriculum: From theory to practice. 2010. Lanham, MD: Rowman and Littlefield.

PINAR, W. Notes on the curriculum field 1978. Educational Researcher, 7(8), 1978, 5-12.

PINAR, W. The synoptic text today and other essays: Curriculum development after reconceptualization. 2006. New York: Peter Lang.

PINAR, W.; REYNOLDS, W.; SLATTERY, P.; TAUBMAN, P. Understanding curriculum: An introduction to the study of historical and contemporary historical discourses. 1995. New York: Peter Lang.

REID, W. A. Rethinking Schwab: Curriculum Theorizing as a Visionary Activity. Journal of Curriculum and Supervision, 17(1), 2004, pp. 29-42.

RENARD, L. Setting new teachers up for failure...or success. Educational Leadership, 60(8), 2003, pp. 62-65.

SCHUBERT, W. H. Toward lives worth sharing: A basis for integrating curriculum. Educational Horizons, 73, 1994, pp. 25-30.

SCHUBERT, W. H. Journeys of expansion and synopsis: Tensions in books that shaped curriculum inquiry, 1968-Present. Curriculum Inquiry, 40(1), 2010, pp. 17-94.

SCHUBERT, W. Curriculum: Perspectives, paradigms, and possibility. 1986, New York: MacMillan.

SCHWAB, J. College curriculum and student protest. 1969. Chicago: University of Chicago Press.

SLATTERY, P. Curriculum development in the postmodern era. 1995. New York: Peter Lang.

STRIPLING, J. Most presidents prefer no tenure for majority of faculty. The chronicle of higher education, May 15, 2011, (www.chronicle.com/article.Most-Presidents-Favor-No/127526/).

TATUSKO, A. M. The tacit media pedagogy as praxial critique: A critique of postmodern theory for higher education curriculum. Teachers College Record, 107(1), 2005, pp. 114-137.

VAN TIL, W. ASCD and social forces. In VAN TIL, W. (Ed.). ASCD in retrospect: Contributions to the history of the Association for Supervision and Curriculum Development. 1986. Washington, D.C.: ASCD.

WESTBURY, I. Reconsidering Schwab's 'practicals': A response to Peter Hlebowitsh's 'Generational ideas in curriculum: A historical triangulation.' Curriculum Inquiry. 35(1), 2005, pp. 89-102.

WILLIAMS, J. A. Aging professors create a faculty bottleneck. The Chronicle of Higher Education, March 18, 2012. (http://chronicle.com/article/Professors-Are-Graying-and/131226). 
Article received on: $27 / 03 / 2018$

Approved on: 31/05/2018

Contact for correspondence:

David Callejo Pérez

E-mail: dmcallej@SVSU.edu 